\title{
Social Networks as a Means of Monitoring Students' Progress
}

\section{Las redes sociales como medio de seguimiento del progreso de los estudiantes}

\author{
Anna Leonidovna Krivova \\ Russian State Social University, Moscow, Russia \\ https://orcid.org/0000-0002-4095-4656 \\ Alexander Konstantinovich Kalliopin \\ Moscow Aviation Institute, Moscow, Russia \\ https://orcid.org/0000-0001-8614-6868 \\ Irina Eduardovna Korotaeva \\ Moscow Aviation Institute, Moscow, Russia \\ https://orcid.org/0000-0002-8300-0836 \\ Natalia Evgenievna Shafazhinskaya \\ K.G. Razumovcky Moscow State University of technologies and management (the First \\ Cossack University), Moscow, Russia \\ https://orcid.org/0000-0003-3260-8566 \\ Daria Yuryevna Ermilova \\ Russian State University of Tourism and Service, Cherkizovo, Moscow region, Russia \\ https://orcid.org/0000-0003-4794-1396
}

*Correspondencia

Email: KrivovaAL@rgsu.net 


\section{Summary}

In the era of the digital educational environment, where each participant of the educational process is actively involved in its development, the Internet and its services have become a popular tool. Open education network tools are defined as ICT tools that ensure the formation and maintenance of network electronic information resources of an open education environment, the implementation of design technologies, and the use of open pedagogical systems. The article aims to reveal methods of monitoring and analyzing students' learning achievements in higher education institutions using social networks. The main research method was a survey. The article justifies the purposefulness and efficiency of the use of social networks in the process of monitoring and analyzing students' progress for new learning achievements. The study concludes that the use of social networks for monitoring and analyzing students' progress ensures the individualization of the learning process and increases the effectiveness of monitoring learning achievements.

Keywords: Social Networks, Types of Progress Monitoring, Learning Achievement Monitoring, Online Resources.

\section{Resumen}

En la era del entorno educativo digital, donde cada participante del proceso educativo participa activamente en su desarrollo, Internet y sus servicios se han convertido en una herramienta popular. Las herramientas de red de educación abierta se definen como herramientas de TIC que garantizan la formación y mantenimiento de recursos de información electrónicos en red de un entorno educativo abierto, la implementación de tecnologías de diseño y el uso de sistemas pedagógicos abiertos. El artículo tiene como objetivo revelar métodos de seguimiento y análisis de los logros de aprendizaje de los estudiantes en instituciones de educación superior utilizando las redes sociales. El principal método de investigación fue una encuesta. El artículo justifica la determinación y la eficiencia del uso de las redes sociales en el proceso de seguimiento y análisis del progreso de los estudiantes en busca de nuevos logros de aprendizaje. El estudio concluye que el uso de las redes sociales para monitorear y analizar el progreso de los estudiantes asegura la individualización del proceso de aprendizaje y aumenta la efectividad del monitoreo de los logros del aprendizaje.

Palabras clave: redes sociales, tipos de seguimiento del progreso, seguimiento del logro de aprendizaje, recursos en línea.

\section{Introduction}

The search for new models of organization of modern students' educational activities is the priority for researchers in the field of pedagogy (Ermilova, 2020; Mazhitova et al., 2020). The reason is in the fact that during the process of teaching a future highly qualified and competitive specialist, the student must not only learn how to learn but also how to correctly use knowledge gained at university (Lyakhova et al., 2020). A graduate's information competence is shaped due to the effective use of modern digital technologies in the educational activities of higher education institutions. However, a problem of methods for monitoring students' learning achievements remains because the classical system is not always objective (Anufrieva et al., 2020; Akhyadov et al., 2020; Shubtsova et al., 2020). 
Relevant for us are such tools of open education systems as distance learning technologies, global social networks, scientific and educational information networks, technologies for connection using mobile devices, etc. (Blin, Munro: 2008; Beldarrain, 2006). Therefore, scientific and pedagogical workers face the most important task, which is the search for new models of the educational process construction in the context of the informatization of the education sector.

Monitoring students' progress plays an important role. The traditional form of teaching is becoming less popular because time-saving high-quality tests are the main trends in the search for new forms of organization of learning achievement monitoring. The modernization of the educational process makes us update the process of monitoring the quality of knowledge and skills through the use of computer technology and communication means (Biloslavo, Trnavcevic, 2007).

Electronic monitoring has a significant list of advantages over the traditional form of knowledge quality control for both teachers and students, namely:

- it allows teachers to quickly check the knowledge of a large number of students on various topics at the same time;

- it frees teachers from performing routine work and organizing mass control, which adds more time to improve the professional activities and develop and use the latest tools;

- it increases the opportunity of implementing individual work with students, which in the new education system is one of the main components since the student receives a third of the knowledge independently (Lau, Tsui, 2009; Liaw et al., 2008).

Therefore, it can be assumed that during the organization of students' progress monitoring, testing using social networks will become popular.

\section{Literature review}

The analysis of the sources indicates the consideration of certain aspects of the possibilities of using social networks in the educational process. In particular, some studies indicate methods of using network tools for information technology support and organization of educational and cognitive activities (Boyd, Ellison: 2007; Arnold, Paulus, 2010). Several scientific works empirically investigate the use of Facebook in the educational process (Ellison et al., 2007; Mazman, Usluel, 2010).

After the analysis of the sources on the problem of using digital technologies, in particular, social networks, we can say that they are very popular among Internet users (Chow, Chan, 2008). This makes it possible to use them in the educational process (Table 1).

Table (1): Options for using social networks in the educational process

\begin{tabular}{|l|l|}
\hline Source & The use of social networks in the educational process \\
\hline $\begin{array}{l}\text { Mason R., } \\
\text { Rennie } \\
(2007)\end{array}$ & $\begin{array}{l}\text { virtual social networks can be used for teaching in groups, self-education; } \\
\text { incidental teaching (the possibility to learn new information unconsciously); } \\
\text { school education (informing about the functioning of educational institutions and } \\
\text { related activities) }\end{array}$ \\
\hline $\begin{array}{l}\text { Blankenship } \\
\text { M. (2011) }\end{array}$ & $\begin{array}{l}\text { every modern teacher should be able to use formal and non-formal teaching } \\
\text { methods, which more often include teaching using electronic social networks }\end{array}$ \\
\hline $\begin{array}{l}\text { Minocha S. } \\
\text { (2009) }\end{array}$ & $\begin{array}{l}\text { the combination of ICT and information and communications networks creates } \\
\text { new solutions that can affect the basic processes of the education system: transfer }\end{array}$ \\
\hline
\end{tabular}




\begin{tabular}{|l|l|}
\hline & $\begin{array}{l}\text { and assimilation of knowledge and skills, achievement fixation, quality of } \\
\text { learning assessment, creation of positive motivation, and stimulation of } \\
\text { independence in educational cognitive activities }\end{array}$ \\
\hline $\begin{array}{l}\text { Siemens G., } \\
\text { Weller M. }\end{array}$ & $\begin{array}{l}\text { After the introduction of social networks in the educational process, they can be } \\
\text { used for the following tasks: } \\
\text { - to organize the teamwork of students in and outside the classroom, which } \\
\text { promotes cooperation and gaining experience of working in teams; } \\
\text { - to expand the organization of teaching students at home, since social networks } \\
\text { allow using educational content, not depending on time, place, and age; } \\
\text { - to develop a personalized learning environment for students, encourage the } \\
\text { creation of a portfolio, and contribute to the educational content; } \\
\text { - to promote self-education of students (the implementation of the teaching } \\
\text { principles on a research basis); } \\
\text { - to encourage the individual learning of students, since students need to work at } \\
\text { their own pace; } \\
\text { - to carry out informal communication between teachers and students; } \\
\text { - to introduce an electronic grade book. }\end{array}$ \\
\hline
\end{tabular}

Despite the diverse scientific research of many aspects of educational virtual communities, the issues of monitoring and analyzing students' progress in higher education institutions, in particular, using social networks, remain relevant and insufficiently studied.

Research hypothesis: The use of social networks in monitoring and analyzing students' progress ensures the individualization of the learning process and increases the effectiveness of monitoring learning achievements.

Research objectives:

- to analyze the possibilities of using various social networks when carrying out progress monitoring;

- to single out the key advantages of using social networks designed to analyze the quality of knowledge assimilation.

The article consists of an introduction, literature review, description of research methods, research results and their discussion, and conclusion.

\section{Methods}

To achieve the goal of the study, we applied the following research methods:

- theoretical methods: a review of scientific, pedagogical, and methodological literature on the theoretical basis of monitoring learning achievements; analysis of online resources, educational software, etc.;

- empirical methods: expert survey, pedagogical experiment;

- numerical methods: mathematical processing of respondents' answers and methods of mathematical statistics.

In the online expert survey, the experts were asked to specify preferable social networks for conducting various types of progress monitoring, as well as indicate the advantages of using social networks for monitoring and analyzing students' progress. 
The experts were 20 teachers from two Russian universities. According to the selection criterion, the experts had been working for at least 6 years in education.

All participants were informed about the purpose of the survey and knew that the authors of the survey would publish the summary of the results.

One hundred twenty-one 3rd-year students took part in the pedagogical experiment. For the control group (55 people), the progress monitoring was organized in the form of a Moodle test; for the experimental group (66 people), in addition to the Moodle test, additional testing was carried out using social networks.

The study included two components:

- the expert survey (10 days), followed by the analysis, interpretation, and presentation of the received data;

- the pedagogical experiment based on the results of the expert survey, followed by the mathematical processing of the results.

\section{Results}

In the process of electronic testing, it is important to choose a testing tool and the type of questions. Several programs and Internet services for creating and carrying out tests exist, but we will focus only on social networks.

The results of the expert survey carried out to determine the most effective social networks for implementing various types of monitoring and analysis of learning achievements are summarized in Table 2 .

Table (2): Social networks for various types of control

\begin{tabular}{|l|l|l|l|l|}
\hline & Preliminary control & Progress control & Periodic control & Final control \\
\hline Google Form & + & + & + & + \\
\hline Kahoot & + & + & + & $+/-*$ \\
\hline Quizalize & + & + & + & $+/-$ * \\
\hline Nearpod & + & + & + & - \\
\hline Instagram & + & - & - & - \\
\hline
\end{tabular}

*According to the experts, it is possible, but not advisable, to use these network services for the final control. It is also possible to use them for updating basic knowledge or for admission to passing the final control (under the condition that the required minimum is met during classroom sessions).

The experts singled out the following advantages of using social networks in the process of monitoring and analyzing students' progress (Table 3).

Table (3): The advantages of using social networks in monitoring and analyzing students' progress

\begin{tabular}{|l|l|l|}
\hline No. & Advantages & $\% *$ \\
\hline 1 & high level of cooperation between students and teachers & $87.5 \%$ \\
\hline 2 & free of charge & $85 \%$ \\
\hline 3 & convenient and intuitive interface & $82.5 \%$ \\
\hline 4 & possibility to create and edit test questions online & $80 \%$ \\
\hline 5 & instant response and instant checking & $77.5 \%$ \\
\hline 6 & convenient methods to analyze results & $75 \%$ \\
\hline 7 & cross-platform social networks (the ability to use them on different devices with & $72.5 \%$ \\
\hline
\end{tabular}


different operational systems: smartphones, tablets, personal computers)

Note: compiled based on the expert survey; ${ }^{*}$ - percentage of expert references

To confirm the research hypothesis, we carried out the statistical analysis of the results of the pedagogical experiment.

As a result of the final testing of the participants in both the control and experimental groups, we obtained the data, which, after testing the statistical hypothesis using Student's t-test, showed the following result: $\mathrm{t}=2.03>\mathrm{t}=1.77$ in the experimental and control groups respectively, with a significance level of $\alpha=0.05$. This means that the levels of solving test tasks by students from the control and experimental groups were different. Students of the experimental group, whose progress was monitored using social networks, showed better results.

\section{Discussion}

Let us consider in more detail social networks for carrying out various types of control, which were identified by the experts.

Google, an American public corporation, provides functionality to support the educational process with additional services and establish students' group educational activities (Iqbal et al., 2018). Groups have the opportunity to add materials, such as lectures and laboratory works, create conversations on a certain topic, where students and teachers can exchange ideas and solve certain aspects of the problem, put forward ideas for improving the learning process, etc. It is possible to add links, videos, and documents (presentations or text files).

In the process of commenting on the posts, it is also possible to add a photo (for example, a screenshot if a problem occurs during laboratory work), a video (for example, a recording of a stage in laboratory or modular work), a sound recording, or a document (a completed laboratory work) from the computer.

The experts paid special attention to one of the tools, Google Form, which makes the usage of Google tools and services more convenient. Today, it is the most popular testing tool because it has all the necessary functions and contains various types of tests (Sivakumar, 2019).

The functions of the Google Form service are diverse and include the possibility to create a large number of questions that can be divided into different groups according to the subject or level of difficulty. It is possible to create a mandatory question (in the form, the required position is determined by an asterisk (*), these elements make it possible to create tests and quizzes of different shape and complexity) or add graphics and videos when creating a test. The main advantage of using Google Form is that the service can carry out a statistical analysis of the results, which are displayed in the form of a table. The statistics show the total number of respondents, the average score, the average level, questions that are often answered incorrectly, and the overall distribution of points. For each question, a graphical interpretation is created in the form of a graph, which reflects (in digital and percentage format) how many respondents indicated an option as a correct answer (Nguyen et al., 2018).

Google Form allows teachers to quickly conduct various quizzes and analyze and view responses. This service is useful for surveying the audience during lectures or progress and final control. The developed test form can be easily integrated into already created Internet applications as a separate frame or as a hyperlink to a document.

The next service is Kahoot, which is a free online service for creating quizzes, questionnaires, and interactive discussions. Students can access the created questions from 
tablets or smartphones using generated code, which makes Kahoot more preferable in comparison with other services. Each question has a regulated time limit. The teacher can optionally introduce a grading system for correctness and speed. The scoreboard is displayed on the teacher's computer with the help of multimedia tools. The only drawback of Kahoot is that surveys are conducted only in real-time and the time limit for answers is set by the teacher. This, in turn, can influence the success in the test (Licorish et al., 2018).

The English-language service Quizalize is intended for the creation of various educational quizzes, tests, and games. Its feature is that students can answer questions both in the classroom and at home. In other words, there is no need for all students to participate simultaneously. During the test creation, it is possible to select only the questions of the test type (questions with one possible answer). Yet, it is possible to add a picture, the time limit for the answer, or an explanation and clarification to the question. The settings for the general type of the test are also can be changed. It is possible to create a random order of questions, set the number of questions on a page, set a time limit for the whole test, and display the test results. After each question, the student sees the current results and the number of points for the answer. The service considers the speed of a student's reaction (Damico, Krutka, 2018).

To update knowledge and to carry out a quiz during the lesson, the experts also advised using the social service Nearpod. It is designed to create presentations that can be transformed into an interactive lesson or just a survey. Access to the presentation is provided with the help of an access code. The site allows adding photos, videos, graphics, and questions to presentations. Thus, students do not psychologically consider it to be a test. They simply browse the educational content and correct answers for the tests. The service has the function of creating open questions, which is useful during lectures for updating knowledge and preliminary control or admission to a practical or laboratory lesson (Delacruz, 2014). The answers appear online and the teacher can examine the situation in the classroom as a whole or for each student individually.

Instagram, which is a popular social network, was created for the exchange of photos and videos between users. However, it can also become a tool for testing students. It has a function of a poll, which can be useful, for example, during a lecture, when there is a need to quickly test the audience. The drawback of these polls is that there are only two options to choose but they can be changed (in other words, the answers are not just "yes" or "no", but there is an opportunity to change them) (Bell, 2013). Poll results are monitored through messages that show the options chosen by respondents. The results are presented in percentage format next to the options.

\section{Conclusion}

We singled out social networks, with the help of which it is possible to carry out effective electronic testing to control the assimilation of educational material by students and analyze the results. The article proposes the approach to using the capabilities of social networks in monitoring and analyzing students' learning achievements. This approach focuses on the implementation of individual educational paths that correspond to the needs and capabilities of each student. The key advantages of using social networks for monitoring and analyzing students' progress are singled out.

The study confirmed the hypothesis that the use of social networks in monitoring and analyzing students' progress ensures the individualization of the learning process and increases the effectiveness of monitoring learning achievements.

Thus, social networks can become one of the powerful auxiliary means for creating and organizing test control of students' learning achievements. The use of such innovative tools expands the possibilities of creating relevant and interactive applications based on ICT, which, 
in the context of integration of a new learning strategy and development of new competencies, is advisable when conducting various types of control.

Further research includes the search for other rational methods to use social networks in the organization of educational and research activities of students of higher education institutions and the development of guidelines for students and teachers regarding the use of social networks in the organization of educational and research activities.

\section{Referencias}

Akhyadov, E.S.-M., Goncharov, V.V., Makushkin, S.A. (2020). Video marketing in education: attracting applicants using the youtube service. Revista Inclusiones, 7(Especial): 387-396.

Anufrieva, N.I., Volkov, L.V., Aralova, E.V., Kolomyts, O.G., Myagkova, E.V. (2020). Environmental Education: Nurturing of the Humanistic Orientation of a Personality. Universal Journal of Educational Research, 8(11): 5529 - 5535. https://doi.org/10.13189/ujer.2020.081156

Arnold, N., Paulus, T. (2010). Using a social networking site for experiential learning: Appropriating, lurking, modeling and community building. The Internet and Higher Education, 13: 188-196. https://doi.org/10.1016/j.iheduc.2010.04.002

Beldarrain, Y. (2006). Distance education trends: Integrating new technologies to foster student interaction and collaboration. Distance Education, 27(2): 139-153. https://doi.org/10.1080/01587910600789498

Bell, M.A. (2013). Picture this! Using Instagram with students. Internet@ Schools, 23(4): 2325.

Biloslavo, R. Trnavcevic, A. (2007). Knowledge Management Audit in a higher education institution: A Case Study. Knowledge and Process Management, 14(4): 275-286.

Blankenship, M. (2011). How social media can and should impact higher education. Education Digest, 76(7): 39-42.

Blin, F., Munro, M. (2008). Why hasn't technology disrupted academics' teaching practices? Understanding resistance to change through the lens of activity theory. Computers \& Education, 50(2): 475-490.

Boyd, M.D., Ellison, N.B. (2007). Social network sites: definition, history, and scholarship. Journal of Computer-Mediated Communication, 13(1): 210-230.

Chow, W., Chan, L. (2008). Social network, social trust and shared goals in organizational knowledge sharing. Information and management, 45(7), 458-465.

Damico, N., Krutka, D.G. (2018). Social media diaries and fasts: Educating for digital mindfulness with pre-service teachers. Teaching and Teacher Education, 73: 109119.

Delacruz, S. (2014). Using Nearpod in elementary guided reading groups. TechTrends, 58(5), 63-70.

Ellison, N.B., Steinfield, C., Lampe, C. (2007). The benefits of Facebook "Friends:" social capital and college students' use of online social network sites. Journal of ComputerMediated Communication, 12(4): 1143-1168.

Ermilova, D.YU. (2020). Costume as a Form of Visualization of Ethnicity: From Tradition to Modernity. Rupkatha Journal on Interdisciplinary Studies in Humanities, 12(6): 1-14.

Iqbal, M., Simarmata, J., Feriyansyah, F., Tambunan, A., Sihite, O., Gandamana, A., Eza, G.N., Kurniawan, F., Asiah, A., Rozi, F., Al Faisal, F., Manurung, I.F.U., Ihwani, M., Nathan, P.L.A., Sitanggang, N., Simbolon, N., Simanjuntak, E.B., Limbong, T. (2018). Using Google form for Student Worksheet as Learning Media. International Journal of Engineering \& Technology, 7(3.4): 321-324.

Lau, A., Tsui, E. (2009). Knowledge management perspective on e-learning effectiveness. Knowledge based systems, 22(4): 324-325.

Liaw, S., Chen, G., Huang, H. (2008). User's attitude towards web-based collaborative learning systems for knowledge management. Computers and Education, 50(3): 950961. 
Licorish, S.A., Owen, H.E., Daniel, B., George, J.L. (2018). Students' perception of Kahoot!'s influence on teaching and learning. Research and Practice in Technology Enhanced Learning, 13(9): 1-23. https://doi.org/10.1186/s41039-018-0078-8

Lyakhova, N.B., Tatyeva, E.V., Rustamov, F.H., Kamarova, N.S. (2020). Technology for conducting online lectures using cloud services in distance education for students of humanitarian specialties. EurAsian Journal of BioSciences, 14: 6189-6195.

Mason, R., Rennie, F. (2007). Using Web 2.0 for learning in the community. The Internet and Higher Education, 10: 196-203. https://doi.org/10.1016/j. iheduc.2007.06.003

Mazhitova, Zh., Atanakova, K., Uskembayev, K. (2020). Convergence of Customary Law and Sharia in the Kazakh Steppe Based on Russian Reports (First Half of the 19th Century). Utopía y Praxis Latinoamericana, 25(Extra 5): 154-162.

Mazman, S.G., Usluel, Y.K. (2010). Modeling educational usage of Facebook. Computers \& Education, 55: 444-453.

Minocha, S. (2009). An empirically-grounded study on the effective use of social software in education. Education + Training, 51(5/6): 381-394.

Nguyen, H., Stehr, E.M., Eisenreich, H., An, T. (2018). Using Google Forms to Inform Teaching Practices. Proceedings of the Interdisciplinary STEM Teaching and Learning Conference, 2(10): 74-79.

Shubtsova, L.V., Kostromina, E.A., Chelyapina, O.I., Grigorieva, N.A., Trifonov, P.V. (2020). Supporting the Tourism Industry in the Context of the Coronavirus Pandemic and Economic Crisis: Social Tourism and Public-Private Partnership. Journal of Environmental Management and Tourism, 11(6): 1427-1434.

Siemens, G., Weller, M. (2011). Higher education and the promises and perils of social network. Revista de Universidad y Sociedad del Conocimiento, 8(1): 164-170.

Sivakumar, R. (2019). Google form in education. Journal of Contemporary Educational Research and Innovations, 9(1): 35-39. 